\title{
The Use of Text Messaging to Improve Clinical Engagement for Individuals With Psychosis: Systematic Review
}

Jessica D'Arcey ${ }^{1,2}$, BSc; Joanna Collaton ${ }^{3}$, MPH; Nicole Kozloff ${ }^{1,4}$, MD, SM; Aristotle N Voineskos ${ }^{1,2,5}$, MD, PhD; Sean A Kidd ${ }^{1,2}$, PhD; George Foussias ${ }^{1,2,5}$, MD, PhD

\footnotetext{
${ }^{1}$ Slaight Centre for Youth in Transition, Centre for Addiction and Mental Health, Toronto, ON, Canada

${ }^{2}$ Institute of Medial Science, University of Toronto, Toronto, ON, Canada

${ }^{3}$ Department of Clinical Psychology, University of Guelph, Guelph, ON, Canada

${ }^{4}$ Institute for Health Policy Management and Evaluation, University of Toronto, Toronto, ON, Canada

${ }^{5}$ Department of Psychiatry, Centre for Addiction and Mental Health, Toronto, ON, Canada
}

\section{Corresponding Author:}

George Foussias, MD, PhD

Slaight Centre for Youth in Transition

Centre for Addiction and Mental Health

250 College St 738

Toronto, ON, M5T1R8

Canada

Phone: 14165358501 ext 34390

Email: george.foussias@camh.ca

\section{Abstract}

Background: Individuals experiencing psychosis are at a disproportionate risk for premature disengagement from clinical treatment. Barriers to clinical engagement typically result from funding constraints causing limited access to and flexibility in services. Digital strategies, such as SMS text messaging, offer a low-cost alternative to potentially improve engagement. However, little is known about the efficacy of SMS text messaging in psychosis.

Objective: This review aimed to address this gap, providing insights into the relationship between SMS text messaging and clinical engagement in the treatment of psychosis.

Methods: Studies examining SMS text messaging as an engagement strategy in the treatment of psychosis were reviewed. Included studies were published from the year 2000 onward in the English language, with no methodological restrictions, and were identified using 3 core databases and gray literature sources.

Results: Of the 233 studies extracted, 15 were eligible for inclusion. Most studies demonstrated the positive effects of SMS text messaging on dimensions of engagement such as medication adherence, clinic attendance, and therapeutic alliance. Studies examining the feasibility of SMS text messaging interventions found that they are safe, easy to use, and positively received.

Conclusions: Overall, SMS text messaging is a low-cost, practical method of improving engagement in the treatment of psychosis, although efficacy may vary by symptomology and personal characteristics. Cost-effectiveness and safety considerations were not adequately examined in the studies included. Future studies should consider personalizing SMS text messaging interventions and include cost and safety analyses to appraise readiness for implementation.

(JMIR Ment Health 2020;7(4):e16993) doi: 10.2196/16993

\section{KEYWORDS}

SMS; text messaging; psychosis; schizophrenia; bipolar disorder; engagement; medication adherence; attendance; patient appointments 


\section{Introduction}

\section{Psychosis and Engagement}

The major psychoses (ie, schizophrenia spectrum and bipolar I disorder) are recognized as a leading cause of disability worldwide [1] and are associated with poverty [2], premature mortality [3], impaired cognitive function [4], loss of education and employment [5], and increased global economic burden [6]. Published practice guidelines outlining the usual treatment for psychosis identify antipsychotic medication as a frontline treatment for positive symptom management and adjunct psychosocial interventions such as psychoeducation, family support, vocational interventions, and cognitive behavioral skills-based therapies [7-11]. However, despite concerted treatment efforts, disengagement from clinical services remains to be a significant barrier to recovery for this population as evidenced by high rates of nonadherence (25\%-50\%) [12], nonattendance (40\%) [13], and service dropout (30\%) [14].

\section{Background}

Clinical engagement is a combination of health-oriented attitudes (ie, beliefs about the cause of illness and intentions of the care team) and behaviors (ie, appointment attendance, adherence to treatment plans, and the level of participation in a clinical relationship) $[15,16]$. Therefore, disengagement occurs when attitudinal factors cause patients to stop performing treatment behaviors such as taking medications and attending appointments [16]. Disengaged individuals often exhibit greater functional impairment and higher symptom burden over time $[17,18]$, subsequently leading to higher rates of relapse and rehospitalization [12,13]. Cycles of relapse and rehospitalization create a unique conundrum for this population as evidence suggests that with each period of disengagement and relapse, positive symptoms become more severe and more difficult to treat [19]. This group is also less likely to fully recover or hold employment [18]. Moreover, studies show that early and sustained engagement in treatment can mitigate negative outcomes of psychosis such as significantly lowering all-cause mortality [20], reducing the risk of relapse [7-11] and ameliorating functional impairment [5,9]. As such, understanding and improving engagement in this population is a priority.

Barriers to clinical engagement are rooted in access to treatment including geographic, systemic, and financial obstacles. Psychosocial services are often located in urbanized areas, serving specific catchment areas [21] and limiting access for rural or remote residents [15,21-23]. Moreover, services are often only available in a business model (ie, Monday-Friday, 9 AM-5 PM) [24-26], with clinicians often treating double the recommended caseloads, further restricting appointment availability [26] because of funding constraints [24-26]. These challenges are often exacerbated by personal factors such as poverty, limited transportation, substance use, trauma history, and beliefs about mental health [15].

Given the financial and staff limitations, there has been a call for more cost-effective, flexible modes of engagement, such as SMS text messaging. SMS text messaging is a globally used mechanism for communication across both wealthy and poor countries [27], and cellular phone ownership and its use in populations with a psychiatric illness is high (72\%-97\%) [28-31]. SMS text messaging offers an easy, user-friendly platform to extend opportunities for engagement beyond clinical boundaries. SMS text messaging also does not require access to a smartphone, wireless internet, or cellular data, making it a more accessible platform for low-income populations, including those with psychosis. These characteristics may allow SMS text messaging to provide support remotely, and in real time, to boost engagement as shown in other areas of health care such as HIV [32], diabetes [33-35], coronary heart disease [36], obesity [37], and substance use disorders [38,39].

\section{This Study}

This systematic review aimed to examine studies investigating SMS text messaging strategies to improve clinical engagement in individuals with psychosis. To date, reviews have focused on the subdomains of clinical engagement such as clinic attendance or medication adherence; however, no such review or single study has examined engagement holistically nor have reviews focused on the use of SMS text messaging within populations with psychosis. This is an important knowledge gap given the challenging nature of engagement in the treatment of psychosis, the resulting considerable outcome disparities, and recent trends toward technologically aided health care. As such, even a modest improvement in clinical engagement could lead to better cost-effectiveness of psychosis treatments [40].

\section{Methods}

\section{Study Inclusion Criteria}

Studies were included regardless of the methodological framework or quality, patient setting (ie, inpatient, outpatient, or community care), age of the population, or stage of illness to provide an inclusive examination of clinical engagement. Studies with a range of quality ratings were included to fully examine the state of the literature on this topic. Included interventions used SMS text messaging as a delivery platform, whereas interventions with mixed or non-SMS text messaging technology (eg, mobile apps) were excluded. This review focused on treatment-seeking individuals with psychosis (ie, the portion of the population either beginning or receiving treatment) to isolate the effect of SMS text messaging on clinical engagement. Although it is true that disengagement is a challenge for those who have yet to be in contact with the mental health care system, attempting to study this population would shift focus from treatment engagement to treatment outreach.

\section{Primary Outcomes: Clinical Engagement}

Clinical engagement is a broad term describing patients' participation in treatment and is typically measured using its behavioral outcomes such as appointment attendance (eg, number or percentage of appointments attended, cancelled, or rescheduled), medication adherence (eg, pill counts, clinician or self-estimates, pharmacy prescriptions, or blood plasma levels), and service dropout (eg, complete disengagement from care). However, the consideration of behavioral outcomes alone does not provide a holistic examination of clinical engagement as it excludes the attitudinal aspects of this complex and nuanced 
concept. To this end, we also included studies with outcomes measuring attitudes toward medication, the level of involvement or participation in treatment plans, and therapeutic rapport.

\section{Secondary Outcomes: Feasibility}

Feasibility studies were also included to assess 2 outcomes: the level of patient engagement with the SMS text messaging intervention itself, and the degree of practicality of SMS text messaging interventions and their ease of implementation. Outcomes of feasibility trials include user feedback on ease of use, satisfaction, likelihood of future use, and overall intervention design. Outcomes related to practicality and implementation include associated risk and economic, technical, and legal considerations. These are important outcomes to consider when assessing the efficacy of interventions because both directly affect the interventions' clinical utility. An intervention of any kind is only as successful as its ability to engage its users. In this case, engagement in the SMS text messaging interventions aims to improve engagement in the treatment of psychosis. Thus, this review examined both aspects of engagement to comprehensively evaluate the efficacy and clinical utility of SMS text messaging interventions to improve clinical engagement in populations with psychosis.

\section{Search Strategy}

Web-based databases cataloging meta-analyses, systematic reviews, and protocols were searched to ensure the originality of this protocol (ie, Cochrane and PROSPERO); however, there were no results on existing reviews on the use of SMS text messaging in psychosis. A unique protocol was, then, created following the Preferred Reporting Items for Systematic reviews and Meta-Analyses guidelines and in consult with a librarian at the University of Toronto. The resulting protocol was registered with PROSPERO (reference number: CRD42018091962), an international protocol registry for prospective reviews in health care managed by the National Institute of Health Research.

In all, 3 core databases powered by OVID were used: PsycINFO, MEDLINE (Medical Literature Analysis and Retrieval System Online), and EMBASE, using the following search strategy: schizophrenia spectrum.mp. OR psychotic disorder.mp. OR exp psychosis/ OR exp bipolar disorder/AND (sms or short messag* service* or texting or text messag*).mp. Please note that .mp. is a mapping command that allows you to search using a word or phrase across titles, keywords, and abstracts using databases powered by OVID.

CINAHL and Google Scholar were used as peripheral databases to ensure studies were not missed. Search terms and keywords related to psychosis and SMS text messaging that were used to search gray literature included the following: (1) SMS OR Short Message Service OR SMS-Survey OR Texting OR Text Message OR SMS Based System OR SMS Reminder OR Text Message Reminder and (2) Psychosis OR Schizophrenia OR Bipolar OR Schizoaffective OR Schizophrenia Spectrum OR
Psychotic Disorders OR First-Episode Psychosis OR Early-Episode Psychosis. Additionally, reference lists of identified studies were hand searched.

The search criteria were limited to studies published in the English language, restricting publication dates from January 2000 to March 2019 as there were no SMS text messaging intervention studies published before the year 2000 .

\section{Review Process}

Studies were independently reviewed by title, abstract, or full-text using a Web-based blinded review platform named Covidence, which allows the reviewers to log-in independently to conduct their review and tracks conflicts to be resolved. Conflicts were resolved first by the 2 primary reviewers, authors JD and JC, and then by a third reviewer, GF, if necessary. Only full-length empirical studies were reviewed; conference abstracts and commentaries were excluded given their limited descriptions of methodologies and inability to be adequately appraised.

\section{Data Extracted}

We extracted sample sizes, and demographic characteristics including age and gender, and diagnoses. Methods were also extracted, including the study design, intervention type, primary and secondary outcome variables, and statistical plan. To better understand the significance of the results, effect sizes were also extracted from studies with randomized controlled trial (RCT) and quasi-experimental designs and converted into a comparable measure of effect size, Cohen $d$. Finally, results reported in each study were extracted, including primary and secondary results (including $P$ values, if available) as well as any other findings of interest to the topic of the review.

\section{Quality Appraisal}

As studies were included regardless of the study design, 3 checklists from the Joanna Briggs toolkit were used: RCTs, quasi-experimental designs, and qualitative studies [41]. This toolkit is an open-access, widely used appraisal tool for systematic reviews accessible through the citation provided. Using the checklist that corresponded to the study type, studies received 1 point per criterion met. Points were tallied and converted to a percentage based on the total number of criteria outlaid on the checklist used for easy comparison across study designs. However, results were compared and contrasted based on the matching outcome variable and study design.

\section{Results}

The original searches of databases yielded 234 studies (Figure 1). The removal of duplicates, as well as a review of titles and abstracts, led to the exclusion of 188 studies. A subsequent full-text review of the remaining 46 articles led to the exclusion of an additional 31 articles, resulting in 15 studies meeting the criteria for inclusion in this review: 8 RCTs, 1 quasi-experimental design, and 6 qualitative studies. 
Figure 1. Flow chart of search results.

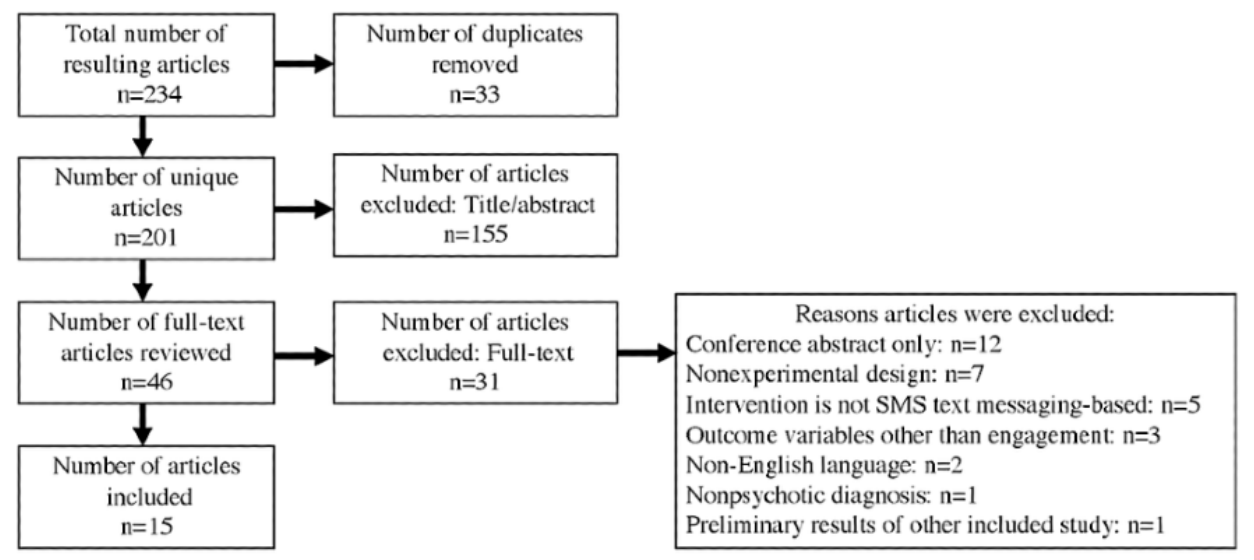

\section{Study Characteristics}

As outlined in Table 1, studies were conducted in a range of countries, although most were Western, developed countries from Europe and North America, with 1 study each from Nigeria, China, and India. They were published from 2010 to 2018, with steady publication rates throughout. Most studies included patients with a diagnosis of schizophrenia spectrum disorders, aged 18 years and older, with 1 study focusing on a younger population, aged 18 to 29 years. Sample sizes ranged from 17 to 1139 with some studies based on the same sample but reporting on different outcomes (eg, studies by Ben-Zeev [42] and Aschbrenner et al [43]; and studies by Kauppi et al [44], Kannisto et al [45], and Välimäki et al [46]). RCTs tended to examine the effects of SMS text messaging reminders on medication adherence and/or clinic attendance paired with secondary outcomes related to symptom severity and functioning. Qualitative studies examined the feasibility and acceptability of SMS text messaging interventions.

Table 1. Characteristics of the studies included.

\begin{tabular}{|c|c|c|c|c|c|c|}
\hline References & Year & Country & Diagnosis/population & Values, $\mathrm{n}$ & Age (years), range (mean) & Male:Female \\
\hline Välimäki et al [46] & 2017 & Finland & Psychosis & $1139^{\mathrm{a}}$ & $18-65(38.3)$ & $1: 2$ \\
\hline Kauppi et al [44] & 2015 & Finland & Psychosis & $562^{\mathrm{a}}$ & $18-65(38.6)$ & $1: 1$ \\
\hline Kannisto et al [45] & 2015 & Finland & Psychosis & $403^{\mathrm{a}}$ & $18-65(39.7)$ & $1: 1$ \\
\hline Montes et al [47] & 2012 & Spain & $\mathrm{SZ}^{\mathrm{b}}$ & 340 & $18-65(39.6)$ & $2: 1$ \\
\hline $\mathrm{Xu}[48]$ & 2017 & China & $\mathrm{SZ}$ & 237 & $35-60(45)$ & $1: 1$ \\
\hline Menon et al [49] & 2018 & India & Bipolar I disorder & 132 & $18-65(37.9)$ & $1: 1$ \\
\hline Beebe et al [50] & 2014 & United States & $\mathrm{SZ}$ and $\mathrm{SZA}^{\mathrm{c}}$ & 30 & $21-68(48.7)$ & $1: 2$ \\
\hline Thomas et al [51] & 2017 & Nigeria & Psychosis & 192 & $18-64(33.7)$ & $1: 1$ \\
\hline Pijnenborg et al [52] & 2010 & Netherlands & SZ spectrum & 62 & $\mathrm{NR}^{\mathrm{d}}(28)$ & $4: 1$ \\
\hline Kravarti et al [53] & 2018 & United Kingdom & SZ spectrum & 75 & NR (42.14) & $1: 1$ \\
\hline Granholm et al [54] & 2012 & United States & SZ and SZA & 55 & $18(48)$ & $2: 1$ \\
\hline Ben-Zeev et al [42] & 2014 & United States & $\mathrm{SZ}, \mathrm{SZA}$, and $\mathrm{SU}^{\mathrm{e}}$ & $28^{\mathrm{f}}$ & $18(40.5)$ & $2: 1$ \\
\hline Aschbrenner et al [43] & 2016 & United States & $\mathrm{SZ}, \mathrm{SZA}$, and $\mathrm{SU}$ & $17^{\mathrm{f}}$ & 18 (NR) & NR \\
\hline Lal et al [55] & 2015 & Canada & Early psychosis & 67 & $18-35(25.6)$ & $3: 1$ \\
\hline Bogart et al [56] & 2014 & United Kingdom & Antipsychotic use & 85 & 18-67 (NR) & $1: 1$ \\
\hline
\end{tabular}

${ }^{\mathrm{a}}$ Indicates a shared sample.

${ }^{\mathrm{b}} \mathrm{SZ}$ : schizophrenia.

${ }^{\mathrm{c}} \mathrm{SZA}$ : schizoaffective disorder.

${ }^{\mathrm{d}} \mathrm{NR}$ : not reported.

${ }^{\mathrm{e}} \mathrm{SU}$ : substance use.

f Indicates a shared sample. 


\section{Appraisal of Study Quality}

Studies included in this review were of a reasonable quality (range 31\%-85\%); however, no study met all of the criteria laid out in the Joanna Briggs frameworks. Individual study ratings are included in Table 2. RCTs received a range of scores from $31 \%$ to $85 \%$, with sample sizes between 28 and 1119 participants. Common unmet criteria in RCTs were blinding expectations, as none of the included trials were double-blinded and many failed to use a concealed assignment. Additionally, some trials were underpowered for their results. In the quasi-experimental study, there was no control group used, causing multiple criteria to be unmet. Qualitative designs tended to satisfy a higher proportion of the quality criteria, receiving scores from $40 \%$ to $80 \%$ with sample sizes ranging from 17 to 562. These studies often lacked information around experimenter bias and sampling methods and an adequate representation of the population. Of note, feasibility studies do not fit smoothly within the qualitative study category and, therefore, appraisal was limited in this domain. Despite these methodological limitations, these studies provide adequate assessments of and insights into a variety of outcomes related to SMS text messaging, clinical engagement, and the consideration of SMS text messaging implementations.
The quality of outcomes within the included studies was fair, although heterogeneous. The included studies showed inconsistent methods of measurement across medication adherence, often relying on self-report, and the calculation of attendance rates was unclear. Other considerations included small sample sizes as 4 of the experimental studies had samples under 100, and only 1 trial had insufficient power to detect a significant difference [50]. The resulting effect sizes were also variable, ranging from moderate to high. Additionally, the intervention design was inconsistent from the type of SMS text messaging (ie, one-way vs two-way messaging) to the frequency, length, and content of the messages themselves. Only 2 of the included studies were designed to include a follow-up period, both examining participants' adherence up to 3 months postintervention $[47,49]$. Taken together, this amount of variance makes it difficult to assess the overall success of the included interventions; however, no clear patterns emerge to suggest that sample size, message type, or effect size varies in response to any methodological factors in these trials. Individual study intervention details are outlined in Table 2 and procedures are outlined in Table 3.

A summary of the main results has been provided in Multimedia Appendix 1. 
Table 2. SMS text messaging intervention details of the studies included that performed a trial.

\begin{tabular}{|c|c|c|c|c|c|c|c|c|c|}
\hline References & Study setting & $\begin{array}{l}\text { Reminder } \\
\text { type }\end{array}$ & $\begin{array}{l}\text { Frequency of } \\
\text { SMS text } \\
\text { messaging }\end{array}$ & Length & $\begin{array}{l}\text { Follow- } \\
\text { up? }\end{array}$ & Compensation & $\begin{array}{l}\text { Delivery } \\
\text { platform }\end{array}$ & $\begin{array}{l}\text { Automated vs } \\
\text { Manual }\end{array}$ & $\begin{array}{l}\text { One- vs } \\
\text { two-way } \\
\text { messaging }\end{array}$ \\
\hline $\begin{array}{l}\text { Välimäki et } \\
\text { al [46], Kan- } \\
\text { nisto et al } \\
\text { [45], Kauppi } \\
\text { et al [44] }{ }^{\text {a }}\end{array}$ & Inpatient discharge & $\begin{array}{l}\text { SMS text } \\
\text { messaging }\end{array}$ & $\begin{array}{l}2 \text { to } 12 \text { mes- } \\
\text { sages per } \\
\text { month based } \\
\text { on the partic- } \\
\text { ipant }\end{array}$ & 1 year & No & $\mathrm{NR}^{\mathrm{b}}$ & $\begin{array}{l}\text { Web plat- } \\
\text { form }\end{array}$ & Semiautomated & One-way \\
\hline $\begin{array}{l}\text { Montes et al } \\
\text { [47] }\end{array}$ & Outpatient/Community & $\begin{array}{l}\text { SMS text } \\
\text { messaging }\end{array}$ & Daily & $\begin{array}{l}3 \\
\text { months }\end{array}$ & $\begin{array}{l}\text { Yes, } 3 \\
\text { months } \\
\text { post }\end{array}$ & NR & $\begin{array}{l}\text { Web plat- } \\
\text { form }\end{array}$ & Automated & One-way \\
\hline Xu [48] & Rural community & $\begin{array}{l}\text { SMS text } \\
\text { messaging } \\
\text { to the pa- } \\
\text { tient/lay } \\
\text { health sup- } \\
\text { port person }\end{array}$ & $\begin{array}{l}\text { Up to } 2 \text { mes- } \\
\text { sages per } \\
\text { day based on } \\
\text { the partici- } \\
\text { pant }\end{array}$ & $\begin{array}{l}6 \\
\text { months }\end{array}$ & No & $\begin{array}{l}\text { Points per re- } \\
\text { sponse in ex- } \\
\text { change for hy- } \\
\text { giene items }\end{array}$ & $\begin{array}{l}\text { Web plat- } \\
\text { form }\end{array}$ & Semiautomated & Two-way \\
\hline $\begin{array}{l}\text { Menon et al } \\
\text { [49] }\end{array}$ & Outpatient & SMS & $\begin{array}{l}2 \text { messages } \\
\text { per week }\end{array}$ & $\begin{array}{l}3 \\
\text { months }\end{array}$ & $\begin{array}{l}\text { Yes, } 3 \\
\text { months } \\
\text { post }\end{array}$ & NR & $\begin{array}{l}\text { Cell } \\
\text { phone }\end{array}$ & $\begin{array}{l}\text { Manual (study } \\
\text { principal investi- } \\
\text { gator) }\end{array}$ & One-way \\
\hline $\begin{array}{l}\text { Beebe et al } \\
\text { [50] }\end{array}$ & Community & $\begin{array}{l}\text { SMS text } \\
\text { messaging } \\
\text { and a call }\end{array}$ & Daily & $\begin{array}{l}3 \\
\text { months }\end{array}$ & No & $\begin{array}{l}\text { US } \$ 10 \text { per } \\
\text { monthly as- } \\
\text { sessment }\end{array}$ & $\begin{array}{l}\text { Cell } \\
\text { phone }\end{array}$ & $\begin{array}{l}\text { Manual (mental } \\
\text { health nurse) }\end{array}$ & Two-way \\
\hline $\begin{array}{l}\text { Thomas et al } \\
\text { [51] }\end{array}$ & Outpatient & $\begin{array}{l}\text { SMS text } \\
\text { messaging }\end{array}$ & $\begin{array}{l}5 \text { and } 3 \text { days } \\
\text { before the } \\
\text { appointment }\end{array}$ & 5 days & No & NR & $\begin{array}{l}\text { Web plat- } \\
\text { form }\end{array}$ & Automated & One-way \\
\hline $\begin{array}{l}\text { Pijnenborg } \\
\text { [52] }\end{array}$ & Outpatient & $\begin{array}{l}\text { SMS text } \\
\text { messaging }\end{array}$ & $\begin{array}{l}1 \text { message } \\
\text { per week }\end{array}$ & 7 weeks & No & NR & $\begin{array}{l}\text { Web plat- } \\
\text { form }\end{array}$ & NR & One-way \\
\hline $\begin{array}{l}\text { Kravariti } \\
{[53]}\end{array}$ & Community & $\begin{array}{l}\text { SMS text } \\
\text { messaging }\end{array}$ & $\begin{array}{l}7 \text { days and } 1 \\
\text { day before } \\
\text { the appoint- } \\
\text { ment }\end{array}$ & $\begin{array}{l}6 \\
\text { months }\end{array}$ & No & Not paid & $\begin{array}{l}\text { Web plat- } \\
\text { form }\end{array}$ & Automated & One-way \\
\hline $\begin{array}{l}\text { Granholm et } \\
\text { al [54] }\end{array}$ & Outpatient & $\begin{array}{l}\text { SMS text } \\
\text { messaging }\end{array}$ & $\begin{array}{l}12 \text { messages } \\
\text { per day }\end{array}$ & $\begin{array}{l}3 \\
\text { months }\end{array}$ & No & $\begin{array}{l}\text { US } \$ 35 \text { for in- } \\
\text { person assess- } \\
\text { ments, US } \$ 20 \\
\text { for text mes- } \\
\text { sage-based as- } \\
\text { sessments }\end{array}$ & $\begin{array}{l}\text { Web plat- } \\
\text { form }\end{array}$ & Automated & Two-way \\
\hline $\begin{array}{l}\text { Been-Zeev } \\
\text { et al [42], } \\
\text { Aschbrenner } \\
\text { et al }[43]^{\mathrm{a}}\end{array}$ & Community & $\begin{array}{l}\text { SMS text } \\
\text { messaging } \\
\text { vs calls }\end{array}$ & $\begin{array}{l}\text { Up to } 3 \text { mes- } \\
\text { sages per } \\
\text { day based on } \\
\text { the prefer- } \\
\text { ence }\end{array}$ & $\begin{array}{l}12 \\
\text { weeks }\end{array}$ & No & $\begin{array}{l}\text { Reimbursed } \\
\text { up to EUR } 30 \\
\text { per month }\end{array}$ & $\begin{array}{l}\text { Cell } \\
\text { phone }\end{array}$ & $\begin{array}{l}\text { Manual (social } \\
\text { worker) }\end{array}$ & Two-way \\
\hline
\end{tabular}

${ }^{\mathrm{a}}$ Indicates a shared sample.

${ }^{\mathrm{b}} \mathrm{NR}$ : not reported. 
Table 3. Methodological characteristics of the study design and methods in the included studies.

\begin{tabular}{|c|c|c|c|c|c|c|c|}
\hline References & Study design & $\begin{array}{l}\text { Engagement } \\
\text { target }\end{array}$ & Primary outcome & Measurement & $\begin{array}{l}\text { Secondary out- } \\
\text { comes }\end{array}$ & Analysis & $\begin{array}{l}\text { Quality rat- } \\
\text { ing }(\%)\end{array}$ \\
\hline \multicolumn{8}{|c|}{ Studies based on intervention trials } \\
\hline Välimäki [46] ${ }^{\mathrm{a}}$ & $\begin{array}{l}\operatorname{RCT}^{\mathrm{b}} 1: 1 \\
\left(\mathrm{TAU}^{\mathrm{c}}\right)\end{array}$ & $\operatorname{MedAd}^{\mathrm{d}}$ & $\begin{array}{l}\text { Number of Hospital- } \\
\text { izations }\end{array}$ & Chart review & $\begin{array}{l}\text { Admission type, } \\
\text { quality of life, } \\
\text { and user satis- } \\
\text { faction }\end{array}$ & $\begin{array}{l}\mathrm{OR}^{\mathrm{e}} \text { and risk } \\
\text { ratio }\end{array}$ & 62 \\
\hline Montes et al [47] & RCT 1:1 (TAU) & MedAd & MedAd & Self-report & $\begin{array}{l}\text { Symptoms, in- } \\
\text { sight, quality of } \\
\text { life, and treat- } \\
\text { ment attitude }\end{array}$ & $\begin{array}{l}\text { Stepwise lin- } \\
\text { ear regression }\end{array}$ & 69 \\
\hline $\mathrm{Xu}[48]$ & $\operatorname{RCT} 1: 1\left(\mathrm{WC}^{\mathrm{f}}\right)$ & $\begin{array}{l}\text { MedAd and Ap- } \\
\text { pAttd }^{\text {g }}\end{array}$ & $\begin{array}{l}\text { MedAd and Ap- } \\
\text { pAttd }\end{array}$ & $\begin{array}{l}\text { Pill count and } \\
\text { scripts }\end{array}$ & $\begin{array}{l}\text { Symptoms and } \\
\text { functioning }\end{array}$ & $\begin{array}{l}\text { Generalized } \\
\text { estimating } \\
\text { equation }\end{array}$ & 85 \\
\hline Menon et al [49] & RCT 1:1 (WC) & $\begin{array}{l}\text { MedAd and } \\
\text { treatment atti- } \\
\text { tude }\end{array}$ & MedAd & Self-report & $\begin{array}{l}\text { Symptoms and } \\
\text { quality of life }\end{array}$ & $\begin{array}{l}\text { Repeated mea- } \\
\text { sures ANO- } \\
\mathrm{VA}^{\mathrm{h}}\end{array}$ & 77 \\
\hline Beebe et al [50] & $\begin{array}{l}\operatorname{RCT} 1: 1: 1^{i} \\
(\mathrm{NC})\end{array}$ & MedAd & MedAd & Pill count & Symptoms & ANOVA & 54 \\
\hline Thomas et al [51] & RCT 1:1 (TAU) & Initial AppAttd & Initial AppAttd & $\begin{array}{l}\text { Attendance di- } \\
\text { chotomous vari- } \\
\text { able (Yes or No) }\end{array}$ & $\begin{array}{l}\text { Duration of un- } \\
\text { treated psy- } \\
\text { chosis and } \\
\text { symptoms }\end{array}$ & OR & 69 \\
\hline $\begin{array}{l}\text { Pijnenborg et al } \\
{[52]}\end{array}$ & RCT 1:1 (WC) & AppAttd & $\begin{array}{l}\text { Number of goals at- } \\
\text { tained (including } \\
\text { AppAttd) }\end{array}$ & $\begin{array}{l}\text { Number of ap- } \\
\text { pointments attend- } \\
\text { ed }\end{array}$ & $\begin{array}{l}\text { Role function- } \\
\text { ing, symptoms, } \\
\text { cognition, and } \\
\text { treatment atti- } \\
\text { tude }\end{array}$ & $\begin{array}{l}\text { Multiple lin- } \\
\text { ear regression }\end{array}$ & 31 \\
\hline $\begin{array}{l}\text { Kravariti et al } \\
{[53]}\end{array}$ & RCT 1:1 (TAU) & AppAttd & AppAttd & $\begin{array}{l}\text { Number of ap- } \\
\text { pointments At- } \\
\text { tended }\end{array}$ & $\mathrm{N} / \mathrm{A}^{\mathrm{j}}$ & $\begin{array}{l}\text { Proportions } \\
(\%), \mathrm{OR}\end{array}$ & 62 \\
\hline $\begin{array}{l}\text { Granholm et al } \\
{[54]}\end{array}$ & $\begin{array}{l}\text { Quasi-Experi- } \\
\text { mental (NCon) }\end{array}$ & MedAd & $\begin{array}{l}\text { MedAd, symptoms, } \\
\text { and socialization }\end{array}$ & $\begin{array}{l}\text { Ambulatory mon- } \\
\text { itoring }\end{array}$ & $\begin{array}{l}\text { Role function- } \\
\text { ing and cogni- } \\
\text { tion }\end{array}$ & HGLM $^{\mathrm{k}}$ & 55 \\
\hline \multicolumn{8}{|c|}{ Studies based on feasibility trials } \\
\hline $\begin{array}{l}\text { Ben-Zeev et al } \\
{[42]^{\mathrm{a}}}\end{array}$ & Feasibility & TxAll & User engagement & Self-report & User feedback & $\begin{array}{l}\text { Proportions } \\
(\%) \text { and paired } \\
t \text { test }\end{array}$ & 80 \\
\hline $\begin{array}{l}\text { Aschbrenner et al } \\
{[43]^{\mathrm{a}}}\end{array}$ & Qualitative & $\begin{array}{l}\text { Reminder inter- } \\
\text { est }\end{array}$ & User interest & $\begin{array}{l}\text { Thematic coding } \\
\text { of SMS text mes- } \\
\text { sages }\end{array}$ & N/A & $\begin{array}{l}\text { Thematic } \\
\text { analysis }\end{array}$ & 70 \\
\hline Lal et al [55] & Feasibility & $\begin{array}{l}\text { Preferred plat- } \\
\text { form }\end{array}$ & User interest & Survey & N/A & $\begin{array}{l}\text { Proportions } \\
(\%)\end{array}$ & 80 \\
\hline Bogart et al [56] & $\begin{array}{l}\text { Feasibility (sur- } \\
\text { vey) }\end{array}$ & MedAd & User feedback & Self-report & N/A & $\begin{array}{l}\text { Proportions } \\
(\%) \text { and step- } \\
\text { wise multilin- } \\
\text { ear regression }\end{array}$ & 40 \\
\hline Kauppi et al $[44]^{\mathrm{a}}$ & Feasibility & $\begin{array}{l}\text { MedAd and Ap- } \\
\text { pAttd }\end{array}$ & Preferred topic & $\begin{array}{l}\text { Patient message } \\
\text { selection }\end{array}$ & $\begin{array}{l}\text { Preferred tim- } \\
\text { ing }\end{array}$ & $\begin{array}{l}\text { Proportions } \\
(\%)\end{array}$ & 60 \\
\hline $\begin{array}{l}\text { Kannisto et al } \\
{[45]^{\mathrm{a}}}\end{array}$ & Feasibility & MedAd & User feedback & Survey & $\begin{array}{l}\text { Preferred topic } \\
\text { and platform }\end{array}$ & $\begin{array}{l}\text { Proportions } \\
(\%)\end{array}$ & 62 \\
\hline
\end{tabular}

${ }^{\mathrm{a}}$ Indicates a shared sample.

${ }^{\mathrm{b}} \mathrm{RCT}$ : randomized controlled trial.

${ }^{\mathrm{c}}$ TAU: treatment as usual.

${ }^{\mathrm{d}}$ MedAd: medication adherence. 
${ }^{\mathrm{e}} \mathrm{OR}$ : odds ratio.

${ }^{f}$ WC: waitlist control.

${ }^{\mathrm{g}}$ AppAttd: appointment adherence.

h ANOVA: analysis of variance.

${ }^{\mathrm{i}}$ Group allocation for this study is daily SMS text messaging only, weekly phone calls only, and a combined group (daily SMS text messaging and weekly phone calls).

${ }^{\mathrm{j}} \mathrm{N} / \mathrm{A}$ : not applicable.

${ }^{\mathrm{k}}$ HGLM: Hierarchical General Linear Modelling.

\section{Primary Outcome: Clinical Engagement}

\section{Medication Adherence}

In total, 6 of the 8 experimental studies were aimed specifically at improvement of medication adherence, with most studies reporting moderate improvements [49-52]; 2 studies reported on the effect of SMS text messaging medication reminders on participatns attitude toward medication, which showed significant improvement over the course of the intervention $[47,48] ; 2$ other studies reported on a follow-up period and found evidence of potential maintenance effects 3 months after the cessation of the SMS text messaging intervention [47,49]; and 1 study did not report positive findings using hospitalization rates as a function of medication adherence as their primary outcome [46].

In total, 3 studies reported a nonsignificant positive change in the overall group that was significant in subgroups. Specifically, efficacy was influenced by baseline adherence and participants' type of living environment such that those with low baseline adherence [48], or those living independently [54], showed significant improvement while individuals with high baseline adherence [48] or those living with a support person [48,54] showed stable and unchanged adherence rates. Additionally, 1 study even included support persons in the design of the SMS text messaging intervention to receive back up SMS text messaging reminders in the event that participants did not respond [48]. This study shows a positive change in adherence, although, unfortunately, it is not clear how much involvement was required from the individual in the support role [48].

An effectiveness trial compared weekly phone calls with a mental health nurse to daily SMS text messaging medication reminders and a combination group [50]. This study found that phone and SMS text messaging reminders showed the most improvement, followed by the phone only group, then SMS text messaging only [50]. This suggests that adherence also may be boosted with the addition of weekly clinician calls. Participants who were prescribed depot medications were included in this study and were unevenly distributed among the treatment groups (phone+SMS text messaging= 3; SMS text messaging only= 5; and phone only=7), which may bias adherence rates favorably for the phone only group [50].

One of the qualitative studies described underlying reasons for nonadherence. Patients reported that a large proportion (49\%) of missed doses were purposeful, rather than owing to forgetfulness (35\%) [56]. The most common reasons for intentionally skipping doses were as follows: side effects, attenuated symptoms, and thinking a lower dose would be more beneficial [56]. Negative attitudes toward medication, insufficient information about medication, and being male led to a 3 to 4 times greater likelihood of reporting purposely skipping doses of medication [56].

\section{Appointment Attendance and Therapeutic Rapport}

In total, 3 studies examined the efficacy of SMS text messaging reminders to improve appointment attendance. Studies demonstrated that SMS text messaging interventions are successful in increasing clinic attendance. SMS text messaging reminders increased the likelihood of attending initial appointments [51] and general attendance during the course of the intervention [52,53]. Studies comparing patient-reported rapport ratings of their usual clinical care teams, and their research-based SMS text messaging interventionist found that, typically, the SMS text messaging interventionist was rated more favorably $[42,48]$. This is interesting given the difference in modality of the relationship, one based in-person and the other purely electronic and text based.

\section{Secondary Outcome: Feasibility}

\section{Practical Considerations}

In total, 5 studies, including both feasibility designs and experimental designs, examined aspects of feasibility, usability, and user satisfaction as outlined in Figure 2. Studies reported a good endorsement of interest (59\%) [56], wanting to continue using the intervention (47\%-64\%) [42,45,52], moderate-to-high ratings of effectiveness $(41 \%-87 \%)$ [42,52], satisfaction $(70 \%-90 \%)$ [42,45,48,52], and ease of use (80\%-98\%) $[42,45,56]$; only a small proportion endorsed harm associated with the intervention (13\%) [45]. Sources of harm included participants finding the SMS text messaging reminder to be disruptive to sleep or work, or annoying [45]. Additionally, 2 studies reported on mobile phone ownership, which was high, ranging from $82 \%$ to $94 \%$ [55,56]. Other practical considerations include legal implications (eg, privacy and personal health information), work load, and cost-effectiveness. One study reported on cost, which estimated the total cost of the texting intervention from a technological and staff perspective but did not analyze how the intervention changed the overall cost in the clinic or if it was cost-efficient [46]. Another study highlighted concerns and considerations around privacy and risks associated with loss, theft, or disposal of mobile phones containing health information, recommending organizations to perform a detailed risk analysis of network security and processes for ensuring informed consent; however, no specific recommendations were made, and privacy was not surveyed or examined in the trial design [42]. 
Figure 2. Feasibility data collected from included studies.

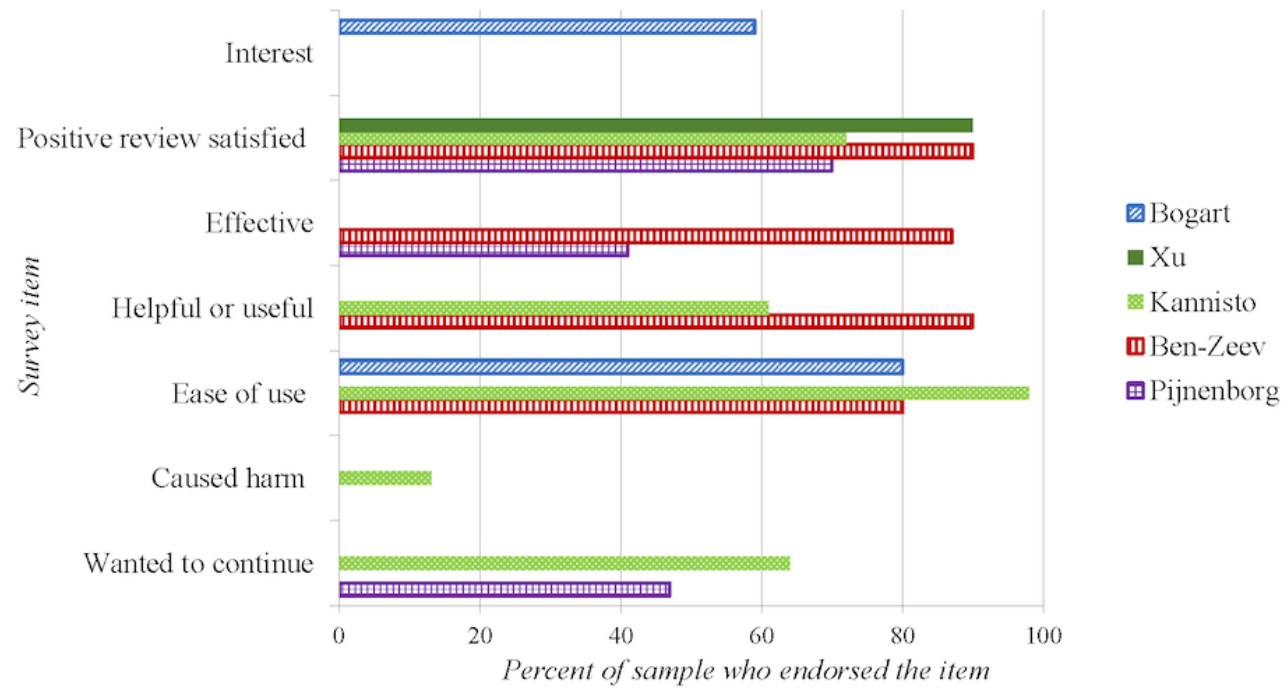

\section{Engagement With the SMS Text Messaging Intervention}

The success of the interventions depended largely on the patients' level of participation and response. In all, 3 studies divided their samples using a participation threshold differentiating who tended to respond to SMS text messages and who did not $[47,52,54]$. The subgroup that tended not to respond to messages showed several demographic and baseline clinical differences. This group was younger, consisted of males, not working or in school, and younger at first contact with treatment [45] and were on polar ends of the clinical and functional spectrum $[47,52,54]$. In a minority of patients, inpatient hospitalization was reported as a barrier to answering SMS text messages as access to mobile devices is sometimes limited [42]. In the group that did tend to respond to SMS text messages, response rates were high, ranging from $85 \%$ to $87 \%$ $[42,54]$ regardless of the message topic [54].

Generally, study attrition rates were low, ranging from $0 \%$ to $20 \%$ (see Table 2). Barriers to using SMS text messaging reported by participants included the following: $22 \%$ reported no interest in using such platforms in care, $20 \%$ reported lack of time, and $30 \%$ reported no barriers; only $7.5 \%$ reported lack of device (cell phone) as a barrier [55]. Limitations in understanding engagement with SMS text messaging are centered around the inability to confirm whether or not patients actually received the SMS text messaging reminder in the absence of a response; thus, one-way SMS text messaging cannot assess SMS text messaging participation at all outside of a participant's report; two-way messaging is still not definitive, as patients may see and not respond to the reminders, leading to reliance on the self-report as well.

\section{User Preferences}

Studies exploring participant preferences examined themes and topics of interest, as well as the frequency and timing of messages. Themes of interest to patients included messages about the following: mental health symptoms, treatment and management (eg, medication and appointments), lifestyle behaviors (eg, exercise, diet, and sleep), social relationships and leisure activity, motivation and goal setting, and independent living [43]. Another study examining personalized SMS text messaging reminders found the most requested reminders were for medication, appointments, and physical health (eg, exercise and diet) [44]. A survey study found that patients were interested in learning about a variety of psychoeducational topics including medication and side effects via digital platforms such as SMS text messaging [55].

Kauppi et al [44] examined trends in operational preferences, reporting that the preferred average number of texts per month was 10 , with a preference for delivery early in the week (eg, Monday or Tuesday) and in the morning (eg, between 6 AM and noon). However, preferences differed according to a number of demographic factors such as age, gender, marital status, living situation, and age at first contact with treatment.

\section{Discussion}

Overall findings support the use of SMS text messaging as a means to enhance engagement in treatment-seeking individuals with psychosis. All but one study demonstrated that an SMS text messaging intervention was associated with improved clinical engagement. Moreover, all studies found that no significant harm was associated with SMS text messaging interventions. Similarly, feasibility findings suggest overall patient endorsement for the use of SMS text messaging in the treatment of psychosis.

\section{Medication}

Using SMS text messaging for medication reminders appears to have a significant positive effect on both attitudes about medication [47] and medication adherence [47,50,54], with the potential to have lasting effects [49]. However, there are many caveats to these findings. First, findings, although positive and significant, had moderate effect sizes based on small samples, with some trials reporting nonsignificant changes or significant changes for only the subgroups of the study sample. Second, most studies did not investigate effects after the termination of the intervention, highlighting a need for additional longitudinal follow-up studies. 
It is also important to acknowledge that medication reminders only address involuntary nonadherence (ie, motivation, forgetfulness, and understanding) and do not directly address voluntary nonadherence (ie, lack of willingness) [57] except potentially indirectly through participants' attitude toward medication. As a cautionary note, this should be considered when evaluating medication reminders as different causes of nonadherence may require different approaches. Furthermore, results indicate SMS text messaging reminders to be most efficacious for patients in a midrange of symptom severity and functioning [47,52,54].

The study that did not find SMS text messaging reminders to have a significant impact on medication adherence used hospital admission rates as the primary outcome [46]. Despite reductions in hospital admissions being one goal of treatment, decreases in hospitalization rates as an indicator of improved medication adherence may be too far removed from the adherence process and may not be an appropriate indicator of the efficacy of SMS text messaging reminders.

The results shown here are similar to those across other areas of health care such that many show positive trends toward improved treatment adherence, with mixed results with regard to significance. For example, some studies find a positive nonsignificant trend toward improved medication adherence in postsurgery populations [58] and individuals with diabetes [33]. Other studies report strong findings in areas such as HIV antiretroviral treatment [32] and general health populations [59]. In contrast, some studies have found no effect of SMS text messaging reminders on populations such as patients with tuberculosis [60].

Some of the aforementioned studies $[33,58]$ as well as many in this review used one-way messaging, which may explain some of the nonsignificant findings. A meta-analysis examining one-way versus two-way SMS text messages as medication reminders found that two-way messaging can increase oral medication adherence in a breadth of medical conditions by $23 \%$, whereas one-way messaging shows little or no effect [61]. In this review, 6 interventions used one-way SMS text messaging reminders, yet only 2 studies found nonsignificant changes in either attendance or medication adherence; thus, one-way reminders may still be effective in psychosis populations.

\section{Attendance}

Regarding clinic attendance, SMS text messaging reminders were also found to increase the likelihood of attending appointments [51,52]. The target population in the study by Thomas et al [51] was patients who had not yet had contact with psychosis services, yet the use of SMS text messaging reminders increased the likelihood of clinic attendance two-fold at initial appointments. Similar findings are reported for initial attendance at treatment start in substance use literature [62]. This is notable considering the high rates of disengagement and dropout for patients in early stages of accessing care [14] and, therefore, represent a population at elevated risk of not receiving treatment.

Findings in this review replicate previous positive findings on attendance within various health conditions and settings, including primary care, mental health care, and dental care, where reminders improve attendance and decrease the probability of missed appointments [63-65]. Taken together, the positive effects of SMS text messaging on clinic attendance may have the potential for annual national cost-savings in the millions [66], and large health insurance providers have begun to consider reimbursement for use of digital aids [31].

\section{Therapeutic Rapport}

Therapeutic rapport may also be enriched by the addition of SMS text messaging as patients in 1 included study reported improved therapeutic rapport with SMS text messaging interventionists compared with their clinical teams [42]. This may be due to factors relating to perceived availability of the mobile interventionist compared with the clinical team [42], as the mobile interventionist is able to reply to questions and problems in real time and communicate with patients daily. This is an important finding given that therapeutic rapport is important for sustained engagement $[14,15]$.

\section{Feasibility}

Feasibility outcomes were assessed by both RCTs and qualitative studies, providing important insights for future implementation. All studies examining user outcomes found SMS text messaging to be feasible, safe, and acceptable, gaining the majority endorsement in each sample [42,44,54-56]. These findings help assuage popular concerns around the feasibility of SMS text messaging interventions as cell phone ownership $[55,56]$ and response rates were high [42,54], most were familiar with SMS text messaging or found it easy to learn and use $[49,52,56]$, and only 1 patient reported increased paranoia around usage of mobile phones [56].

In comparison with other mobile strategies such as mobile apps, SMS text messaging studies reported slightly higher response/usage rates $(83 \%-87 \%)$ than mobile app studies (69\%-86\%) in this population [29], although attrition rates were similar [29]. In a direct comparison of SMS text messaging and mobile apps for daily symptom monitoring, authors noted that the set up used for apps is a more involved process and may affect participation rate; however, the user platform in apps was preferred over SMS text messaging by participants [67].

A clear advantage of SMS text messaging over mobile apps is cell phone versus smartphone ownership, and concerns around the exclusion of economically disadvantaged populations, such as those reliant on government financial support. Cell phone ownership steadily decreases with income and is significantly lower among individuals with severe mental illness (SMI). Ownership among earners of an annual income under US $\$ 30,000$ per year is $84 \%$ and $81 \%$ for those with psychosis, yet ownership among the lowest earners drops to $50 \%$ and $35 \%$, respectively [29]. Cell phone ownership among SMI populations has been reported at $93 \%$ in the United States, yet only $50 \%$ to $60 \%$ owned smartphones $[68,69]$, and $67.9 \%$ in Israel [70]. In developing and newly developed countries such as India, however, smartphone ownership is still only present in a minority $(22.7 \%)$ of mental health populations [71]. Importantly, trends in smartphone ownership, although still below cell phone ownership rates as of 2018, have been steadily increasing for 
years in the general population [72] as well as populations with psychosis [29] and will likely become more ubiquitous as younger populations grow in this digital age.

\section{Strengths and Limitations}

A strength of this review is that we took a comprehensive perspective to engagement and provided an inclusive review of clinical engagement in populations with psychosis [14]. However, an even more comprehensive examination of technologically aided engagement could have been created by including other platforms that use mobile devices, such as mobile apps, as a helpful comparison group. This would help further elucidate patient preferences and effectiveness to ascertain information on which platform is best suited for implementation in the treatment of psychosis. Another limitation of this review may be the design itself, as a review is limited to data extracted from the published articles of the included studies, without attempts to contact corresponding authors of the included studies to obtain further information. In addition, this review was designed and registered as a qualitative review rather than a meta-analysis, although we acknowledge that a meta-analysis may have provided some more quantitative insights into the use of SMS text messaging to boost engagement in the treatment of psychosis; the meta-analysis itself would be limited given the small number of published studies and the significant heterogeneity in methods, primary outcomes, and durations of interventions..

Limited conclusions can be drawn from included studies owing to the scarcity of effectiveness trials and novelty of digital strategies in the treatment of psychosis. Additionally, many current trials are pilot studies that are time-limited with small sample sizes using convenience sampling and, in some cases, with underpowered analyses. Another limitation is that no study examined impacts on clinician workflow or cost-effectiveness or privacy considerations beyond educating participants on privacy risks. Furthermore, there are no standard measurements for clinical engagement or any of its domains, making results too heterogeneous to be accurately compared.

\section{Future Directions}

The central theme drawn from the presented studies is that individuals with psychosis prefer a person-centered approach, with a personal feel, and that this approach tends to be more effective. Suggestions for future trials using SMS text messaging include the involvement of participants in co-design, employing two-way messaging to engage participants in a conversation and allowing for personal choice and autonomy within the intervention, namely personal choice over content, timing, and frequency. This is especially important given the considerable heterogeneity in psychosis spectrum disorders and the flexibility of SMS text messaging to afford opportunities for individualized treatment approaches. Moreover, digital tools have the potential to increase patient autonomy and independence by extending care outside the clinic and putting it literally in patients' hands.

Given the heterogeneity of clinical presentation and treatment, it should also be considered that not all patients with psychosis are prescribed medication, so standalone medication reminders would not be universally helpful. Other subgroups requiring additional planning include individuals with physical disabilities, low literacy levels, severe cognitive impairments, developmental delays, experiencing homelessness, or share a cell phone with others [42]. Another key area of consideration is safety protocols. Despite a study's report that several urgent issues had to be escalated to the primary care team resulting in expedited prescription fills, home visits, and safety assessments [43], none of the included studies reference precautions or procedures relating to safety. Such issues underscore the importance of developing safety protocols for digital tools.

Finally, due to the potential increase in patient autonomy and independence, SMS text messaging-augmented care could lead to a decreased dependence on clinical staff, allowing clinicians more flexibility to manage caseloads and potentially leading to positive financial and economic outcomes while simultaneously allowing for better, more personalized care. Future studies should, therefore, report on the cost-effectiveness of the interventions as well as impact on workflow to assess how readily SMS text messaging can be implemented.

\section{Conclusions}

In sum, this review demonstrates the potential of SMS text messaging to be used as an adjunct platform to support clinical treatment as a means of improved engagement. These findings show that SMS text messaging is extremely well tolerated, safe, and accepted among individuals with psychosis, testifying to its potential to not only improve engagement in care but also to extend care beyond the clinic. To this end, SMS text messaging stands to offer a pragmatic solution to boost clinical engagement and provide an alternative avenue to access treatment. To this end, a more thorough examination of practical considerations, consistent measures for engagement factors, and rigorous examinations of its outcomes (eg, medication blood plasma levels or electronic medication caps compared with self-reporting) are required to adequately assess its efficacy, cost-effectiveness, and readiness for implementation.

\section{Acknowledgments}

All author credits have been listed. The authors would also like to acknowledge Heather Cunningham from Gerstein Library Research Services at the University of Toronto who was instrumental in guiding the search strategy and protocol development.

\section{Conflicts of Interest}

None declared. 


\section{Multimedia Appendix 1}

Summary of results for included studies.

[DOCX File, 22 KB-Multimedia Appendix 1]

\section{References}

1. World Health Organization. World Health Report 2001 - Mental Health: New Understanding, New Hope. Geneva: World Health Organization; 2001.

2. Murali V, Oyebode F. Poverty, social inequality and mental health. Adv Psychiatr Treat 2004;10(3):216-224. [doi: 10.1192/apt.10.3.216]

3. Schoenbaum M, Sutherland J, Chappel A, Azrin S, Goldstein AB, Rupp A, et al. Twelve-month health care use and mortality in commercially insured young people with incident psychosis in the United States. Schizophr Bull 2017 Oct 21;43(6):1262-1272 [FREE Full text] [doi: 10.1093/schbul/sbx009] [Medline: 28398566]

4. Green MF. Cognitive impairment and functional outcome in schizophrenia and bipolar disorder. J Clin Psychiatry 2006;67(Suppl 9):3-8; discussion 36 [FREE Full text] [doi: 10.4088/jcp.1006e12] [Medline: 16965182]

5. Iyer S, Mustafa S, Gariépy G, Shah J, Joober R, Lepage M, et al. A NEET distinction: youths not in employment, education or training follow different pathways to illness and care in psychosis. Soc Psychiatry Psychiatr Epidemiol 2018 Dec;53(12):1401-1411 [FREE Full text] [doi: 10.1007/s00127-018-1565-3] [Medline: 30094632]

6. Chong HY, Teoh SL, Wu DB, Kotirum S, Chiou CF, Chaiyakunapruk N. Global economic burden of schizophrenia: a systematic review. Neuropsychiatr Dis Treat 2016;12:357-373 [FREE Full text] [doi: 10.2147/NDT.S96649] [Medline: 26937191]

7. Gaebel W, Weinmann S, Sartorius N, Rutz W, McIntyre JS. Schizophrenia practice guidelines: international survey and comparison. Br J Psychiatry 2005 Sep;187:248-255. [doi: 10.1192/bjp.187.3.248] [Medline: 16135862]

8. Pringsheim T, Addington D. Canadian schizophrenia guidelines: introduction and guideline development process. Can J Psychiatry 2017 Sep;62(9):586-593 [FREE Full text] [doi: 10.1177/0706743717719897] [Medline: 28789558]

9. Lehman AF, Lieberman JA, Dixon L, McGlashan TH, Miller AL, Perkins DO, American Psychiatric Association, Steering Committee on Practice Guidelines. Practice guideline for the treatment of patients with schizophrenia, second edition. Am J Psychiatry 2004 Feb;161(2 Suppl):1-56. [Medline: 15000267]

10. Addington D, Abidi S, Garcia-Ortega I, Honer WG, Ismail Z. Canadian guidelines for the assessment and diagnosis of patients with schizophrenia spectrum and other psychotic disorders. Can J Psychiatry 2017 Sep;62(9):594-603 [FREE Full text] [doi: 10.1177/0706743717719899] [Medline: 28730847]

11. Bowden CL, Hirschfeld RM, Keck PE, Gitlin MJ, Suppes T, Thase ME, et al. Psychiatry Online. 2010. Practice Guideline for the Treatment of Patients With Bipolar Disorder Second Edition URL: https://psychiatryonline.org/pb/assets/raw/ sitewide/practice guidelines/guidelines/bipolar.pdf [accessed 2020-02-04]

12. Nosé M, Barbui C, Tansella M. How often do patients with psychosis fail to adhere to treatment programmes? A systematic review. Psychol Med 2003 Oct;33(7):1149-1160. [doi: 10.1017/s0033291703008328] [Medline: 14580069]

13. Killaspy H, Banerjee S, King M, Lloyd M. Prospective controlled study of psychiatric out-patient non-attendance. Characteristics and outcome. Br J Psychiatry 2000 Feb;176:160-165. [doi: 10.1192/bjp.176.2.160] [Medline: 10755054]

14. Doyle R, Turner N, Fanning F, Brennan D, Renwick L, Lawlor E, et al. First-episode psychosis and disengagement from treatment: a systematic review. Psychiatr Serv 2014 May 1;65(5):603-611. [doi: 10.1176/appi.ps.201200570] [Medline: 24535333]

15. Becker KD, Buckingham SL, Rith-Najarian L, Kline ER. The Common Elements of treatment engagement for clinically high-risk youth and youth with first-episode psychosis. Early Interv Psychiatry 2016 Dec;10(6):455-467. [doi: 10.1111/eip.12283] [Medline: 26486257]

16. Tindall R, Francey S, Hamilton B. Factors influencing engagement with case managers: perspectives of young people with a diagnosis of first episode psychosis. Int J Ment Health Nurs 2015 Aug;24(4):295-303. [doi: 10.1111/inm.12133] [Medline: 25976922]

17. Kreyenbuhl J, Nossel IR, Dixon LB. Disengagement from mental health treatment among individuals with schizophrenia and strategies for facilitating connections to care: a review of the literature. Schizophr Bull 2009 Jul;35(4):696-703 [FREE Full text] [doi: 10.1093/schbul/sbp046] [Medline: 19491314]

18. Conus P, Lambert M, Cotton S, Bonsack C, McGorry PD, Schimmelmann BG. Rate and predictors of service disengagement in an epidemiological first-episode psychosis cohort. Schizophr Res 2010 May;118(1-3):256-263. [doi: 10.1016/j.schres.2010.01.032] [Medline: 20206475]

19. Ascher-Svanum H, Zhu B, Faries DE, Salkever D, Slade EP, Peng X, et al. The cost of relapse and the predictors of relapse in the treatment of schizophrenia. BMC Psychiatry 2010 Jan 7;10:2 [FREE Full text] [doi: 10.1186/1471-244X-10-2] [Medline: 20059765]

20. Anderson KK, Norman R, MacDougall A, Edwards J, Palaniyappan L, Lau C, et al. Effectiveness of early psychosis intervention: comparison of service users and nonusers in population-based health administrative data. Am J Psychiatry 2018 May 1;175(5):443-452. [doi: 10.1176/appi.ajp.2017.17050480] [Medline: 29495897] 
21. Iyer S, Jordan G, MacDonald K, Joober R, Malla A. Early intervention for psychosis: a Canadian perspective. J Nerv Ment Dis 2015 May;203(5):356-364. [doi: 10.1097/NMD.0000000000000288] [Medline: 25900548]

22. Boydell KM, Pong R, Volpe T, Tilleczek K, Wilson E, Lemieux S. Family perspectives on pathways to mental health care for children and youth in rural communities. J Rural Health 2006;22(2):182-188. [doi: 10.1111/j.1748-0361.2006.00029.x] [Medline: 16606432$]$

23. Ronis ST, Slaunwhite AK, Malcom KE. Comparing strategies for providing child and youth mental health care services in Canada, the United States, and the Netherlands. Adm Policy Ment Health 2017 Nov;44(6):955-966. [doi: 10.1007/s 10488-017-0808-z] [Medline: 28612298]

24. Lal S, Malla A. Service engagement in first-episode psychosis: Current issues and future directions. Can J Psychiatry 2015 Aug;60(8):341-345 [FREE Full text] [doi: 10.1177/070674371506000802] [Medline: 26454555]

25. Malla A, Iyer S, McGorry P, Cannon M, Coughlan H, Singh S, et al. From early intervention in psychosis to youth mental health reform: a review of the evolution and transformation of mental health services for young people. Soc Psychiatry Psychiatr Epidemiol 2016 Mar;51(3):319-326. [doi: 10.1007/s00127-015-1165-4] [Medline: 26687237]

26. Nolin M, Malla A, Tibbo P, Norman R, Abdel-Baki A. Early intervention for psychosis in Canada: What is the State of Affairs? Can J Psychiatry 2016 Mar;61(3):186-194 [FREE Full text] [doi: 10.1177/0706743716632516] [Medline: 27254094]

27. Jones KR, Lekhak N, Kaewluang N. Using mobile phones and short message service to deliver self-management interventions for chronic conditions: a meta-review. Worldviews Evid Based Nurs 2014 Apr;11(2):81-88. [doi: 10.1111/wvn.12030] [Medline: 24597522]

28. Firth J, Torous J. Smartphone apps for schizophrenia: a systematic review. JMIR Mhealth Uhealth 2015 Nov 6;3(4):e102 [FREE Full text] [doi: 10.2196/mhealth.4930] [Medline: 26546039]

29. Firth J, Cotter J, Torous J, Bucci S, Firth JA, Yung AR. Mobile phone ownership and endorsement of 'mHealth' among people with psychosis: a meta-analysis of cross-sectional studies. Schizophr Bull 2016 Mar;42(2):448-455 [FREE Full text] [doi: 10.1093/schbul/sbv132] [Medline: 26400871]

30. Ben-Zeev D, Kaiser SM, Brenner CJ, Begale M, Duffecy J, Mohr DC. Development and usability testing of FOCUS: a smartphone system for self-management of schizophrenia. Psychiatr Rehabil J 2013 Dec;36(4):289-296 [FREE Full text] [doi: 10.1037/prj0000019] [Medline: 24015913]

31. Carras MC, Mojtabai R, Furr-Holden CD, Eaton W, Cullen BA. Use of mobile phones, computers and internet among clients of an inner-city community psychiatric clinic. J Psychiatr Pract 2014 Mar;20(2):94-103 [FREE Full text] [doi: 10.1097/01.pra.0000445244.08307.84] [Medline: 24638044]

32. Lester RT, Ritvo P, Mills EJ, Kariri A, Karanja S, Chung MH, et al. Effects of a mobile phone short message service on antiretroviral treatment adherence in Kenya (WelTel Kenya1): a randomised trial. Lancet 2010 Nov 27;376(9755):1838-1845. [doi: 10.1016/S0140-6736(10)61997-6] [Medline: 21071074]

33. Sugita H, Shinohara R, Yokomichi H, Suzuki K, Yamagata Z. Effect of text messages to improve health literacy on medication adherence in patients with type 2 diabetes mellitus: A randomized controlled pilot trial. Nagoya J Med Sci 2017 Aug;79(3):313-321 [FREE Full text] [doi: 10.18999/nagjms.79.3.313] [Medline: 28878436]

34. Lari H, Noroozi A, Tahmasebi R. Comparison of multimedia and SMS education on the physical activity of diabetic patients: an application of health promotion model. Iran Red Crescent Med J 2018;20(s1):e59800. [doi: 10.5812/ircmj.59800]

35. Kaushal T, Montgomery KA, Simon R, Lord K, Dougherty J, Katz LEL, et al. MyDiaText: feasibililty and functionality of a text messaging system for youth with Type 1 Diabetes. Diabetes Educ 2019 Jun;45(3):253-259. [doi: 10.1177/0145721719837895] [Medline: 30902038]

36. Islam SM, Chow CK, Redfern J, Kok C, Rådholm K, Stepien S, et al. Effect of text messaging on depression in patients with coronary heart disease: a substudy analysis from the TEXT ME randomised controlled trial. BMJ Open 2019 Feb 20;9(2):e022637 [FREE Full text] [doi: 10.1136/bmjopen-2018-022637] [Medline: 30787075]

37. Keating SR, McCurry M. Text messaging as an intervention for weight loss in emerging adults. J Am Assoc Nurse Pract 2019 Sep;31(9):527-536. [doi: 10.1097/JXX.0000000000000176] [Medline: 30908408]

38. Song T, Qian S, Yu P. Mobile health interventions for self-control of unhealthy alcohol use: systematic review. JMIR Mhealth Uhealth 2019 Jan 29;7(1):e10899 [FREE Full text] [doi: 10.2196/10899] [Medline: $\underline{30694200]}$

39. Mason M, Ola B, Zaharakis N, Zhang J. Text messaging interventions for adolescent and young adult substance use: a meta-analysis. Prev Sci 2015 Feb;16(2):181-188. [doi: 10.1007/s11121-014-0498-7] [Medline: 24930386]

40. Kauppi K, Välimäki M, Hätönen HM, Kuosmanen LM, Warwick-Smith K, Adams CE. Information and communication technology based prompting for treatment compliance for people with serious mental illness. Cochrane Database Syst Rev 2014 Jun 17(6):CD009960. [doi: 10.1002/14651858.CD009960.pub2] [Medline: 24934254]

41. Tufanaru C, Munn Z, Aromataris E, Campbell J, Hopp L. Joanna Briggs Institute. 2017. JBI Reviewer's Manual - Chapter 3: Systematic reviews of effectiveness URL: https://reviewersmanual.joannabriggs.org/ [accessed 2020-02-04]

42. Ben-Zeev D, Kaiser SM, Krzos I. Remote 'hovering' with individuals with psychotic disorders and substance use: feasibility, engagement, and therapeutic alliance with a text-messaging mobile interventionist. J Dual Diagn 2014;10(4):197-203 [FREE Full text] [doi: 10.1080/15504263.2014.962336] [Medline: 25391277] 
43. Aschbrenner KA, Naslund JA, Gill LE, Bartels SJ, Ben-Zeev D. A qualitative study of client-clinician text exchanges in a mobile health intervention for individuals with psychotic disorders and substance use. J Dual Diagn 2016;12(1):63-71 [FREE Full text] [doi: 10.1080/15504263.2016.1145312] [Medline: 26829356]

44. Kauppi K, Kannisto KA, Hätönen H, Anttila M, Löyttyniemi E, Adams CE, et al. Mobile phone text message reminders: measuring preferences of people with antipsychotic medication. Schizophr Res 2015 Oct;168(1-2):514-522. [doi: 10.1016/j.schres.2015.07.044] [Medline: 26293215]

45. Kannisto KA, Adams CE, Koivunen M, Katajisto J, Välimäki M. Feedback on SMS reminders to encourage adherence among patients taking antipsychotic medication: a cross-sectional survey nested within a randomised trial. BMJ Open 2015 Nov 9;5(11):e008574 [FREE Full text] [doi: 10.1136/bmjopen-2015-008574] [Medline: 26553830]

46. Välimäki M, Kannisto KA, Vahlberg T, Hätönen H, Adams CE. Short text messages to encourage adherence to medication and follow-up for people with psychosis (mobile.net): Randomized controlled trial in Finland. J Med Internet Res 2017 Jul 12;19(7):e245 [FREE Full text] [doi: 10.2196/jmir.7028] [Medline: 28701292]

47. Montes JM, Medina E, Gomez-Beneyto M, Maurino J. A short message service (SMS)-based strategy for enhancing adherence to antipsychotic medication in schizophrenia. Psychiatry Res 2012 Dec 30;200(2-3):89-95. [doi: 10.1016/j.psychres.2012.07.034] [Medline: 22901437]

48. Xu D. University Libraries - University of Washington. 2017. Effectiveness of Mobile Text Messaging to Improve Schizophrenia Adherence, Symptoms and Functioning in a Resource-poor Community Setting: 'LEAN' Randomized Controlled Trial URL: https://digital.lib.washington.edu/researchworks/bitstream/handle/1773/40805/ Xu_washington_0250E_18081.pdf?sequence=1\&isAllowed=y [accessed 2020-02-04]

49. Menon V, Selvakumar N, Kattimani S, Andrade C. Therapeutic effects of mobile-based text message reminders for medication adherence in bipolar I disorder: Are they maintained after intervention cessation? J Psychiatr Res 2018 Sep;104:163-168. [doi: 10.1016/j.jpsychires.2018.07.013] [Medline: 30081390]

50. Beebe L, Smith KD, Phillips C. A comparison of telephone and texting interventions for persons with schizophrenia spectrum disorders. Issues Ment Health Nurs 2014 May;35(5):323-329. [doi: 10.3109/01612840.2013.863412] [Medline: 24766166]

51. Thomas IF, Lawani AO, James BO. Effect of short message service reminders on clinic attendance among outpatients with psychosis at a psychiatric hospital in Nigeria. Psychiatr Serv 2017 Jan 1;68(1):75-80. [doi: 10.1176/appi.ps.201500514] [Medline: 27582239]

52. Pijnenborg GH, Withaar FK, Brouwer WH, Timmerman ME, van den Bosch RJ, Evans JJ. The efficacy of SMS text messages to compensate for the effects of cognitive impairments in schizophrenia. Br J Clin Psychol 2010 Jun;49(Pt 2):259-274. [doi: 10.1348/014466509X467828] [Medline: 19735607$]$

53. Kravariti E, Reeve-Mates C, da Gama Pires R, Tsakanikos E, Hayes D, Renshaw S, et al. Effectiveness of automated appointment reminders in psychosis community services: a randomised controlled trial. BJPsych Open 2018 Jan;4(1):15-17 [FREE Full text] [doi: 10.1192/bjo.2017.7] [Medline: 29388909]

54. Granholm E, Ben-Zeev D, Link PC, Bradshaw KR, Holden JL. Mobile Assessment and Treatment for Schizophrenia (MATS): a pilot trial of an interactive text-messaging intervention for medication adherence, socialization, and auditory hallucinations. Schizophr Bull 2012 May;38(3):414-425 [ [FREE Full text] [doi: 10.1093/schbul/sbr155] [Medline: 22080492]

55. Lal S, Dell'Elce J, Tucci N, Fuhrer R, Tamblyn R, Malla A. Preferences of young adults with first-episode psychosis for receiving specialized mental health services using technology: a survey study. JMIR Ment Health 2015;2(2):e18 [FREE Full text] [doi: 10.2196/mental.4400] [Medline: 26543922]

56. Bogart K, Wong SK, Lewis C, Akenzua A, Hayes D, Prountzos A, et al. Mobile phone text message reminders of antipsychotic medication: is it time and who should receive them? A cross-sectional trust-wide survey of psychiatric inpatients. BMC Psychiatry 2014 Jan 22;14:15 [FREE Full text] [doi: 10.1186/1471-244X-14-15] [Medline: 24447428]

57. Steinkamp JM, Goldblatt N, Borodovsky JT, LaVertu A, Kronish IM, Marsch LA, et al. Technological interventions for medication adherence in adult mental health and substance use disorders: a systematic review. JMIR Ment Health 2019 Mar 12;6(3):e12493 [FREE Full text] [doi: 10.2196/12493] [Medline: 30860493]

58. Brix LD, Bjørnholdt KT, Thillemann TM, Nikolajsen L. The effect of text messaging on medication adherence after outpatient knee arthroscopy: a randomized controlled trial. J Perianesth Nurs 2019 Aug;34(4):710-716. [doi: 10.1016/j.jopan.2018.11.011] [Medline: $\underline{30852173}$ ]

59. Moore DJ, Poquette A, Casaletto KB, Gouaux B, Montoya JL, Posada C, HIV Neurobehavioral Research Program (HNRP) Group. Individualized texting for adherence building (iTAB): improving antiretroviral dose timing among HIV-infected persons with co-occurring bipolar disorder. AIDS Behav 2015 Mar;19(3):459-471 [FREE Full text] [doi: 10.1007/s10461-014-0971-0] [Medline: 25504449]

60. Liu X, Lewis JJ, Zhang H, Lu W, Zhang S, Zheng G, et al. Effectiveness of electronic reminders to improve medication adherence in tuberculosis patients: a cluster-randomised trial. PLoS Med 2015 Sep;12(9):e1001876 [FREE Full text] [doi: 10.1371/journal.pmed.1001876] [Medline: 26372470]

61. Wald DS, Butt S, Bestwick JP. One-way versus two-way text messaging on improving medication adherence: meta-analysis of randomized trials. Am J Med 2015 Oct;128(10):1139.e1-1139.e5. [doi: 10.1016/j.amjmed.2015.05.035] [Medline: 26087045] 
62. Kmiec J, Suffoletto B. Implementations of a text-message intervention to increase linkage from the emergency department to outpatient treatment for substance use disorders. J Subst Abuse Treat 2019 May;100:39-44. [doi: 10.1016/j.jsat.2019.02.005] [Medline: $\underline{30898326}$ ]

63. Kannisto KA, Koivunen MH, Välimäki MA. Use of mobile phone text message reminders in health care services: a narrative literature review. J Med Internet Res 2014 Oct 17;16(10):e222 [FREE Full text] [doi: 10.2196/jmir.3442] [Medline: 25326646]

64. Robotham D, Satkunanathan S, Reynolds J, Stahl D, Wykes T. Using digital notifications to improve attendance in clinic: systematic review and meta-analysis. BMJ Open 2016 Oct 24;6(10):e012116 [FREE Full text] [doi: 10.1136/bmjopen-2016-012116] [Medline: 27798006]

65. Schwebel FJ, Larimer ME. Using text message reminders in health care services: a narrative literature review. Internet Interv 2018 Sep;13:82-104 [FREE Full text] [doi: 10.1016/j.invent.2018.06.002] [Medline: 30206523]

66. Sims H, Sanghara H, Hayes D, Wandiembe S, Finch M, Jakobsen H, et al. Text message reminders of appointments: a pilot intervention at four community mental health clinics in London. Psychiatr Serv 2012 Feb 1;63(2):161-168. [doi: 10.1176/appi.ps.201100211] [Medline: 22302334]

67. Ainsworth J, Palmier-Claus JE, Machin M, Barrowclough C, Dunn G, Rogers A, et al. A comparison of two delivery modalities of a mobile phone-based assessment for serious mental illness: native smartphone application vs text-messaging only implementations. J Med Internet Res 2013 Apr 5;15(4):e60 [FREE Full text] [doi: 10.2196/jmir.2328] [Medline: $\underline{23563184]}$

68. Gitlow L, Abdelaal F, Etienne A, Hensley J, Krukowski E, Toner M. Exploring the current usage and preferences for everyday technology among people with serious mental illnesses. Occup Ther Ment Heal 2017;33(1):1-14. [doi: 10.1080/0164212X.2016.1211061]

69. Naslund JA, Aschbrenner KA, Bartels SJ. How people with serious mental illness use smartphones, mobile apps, and social media. Psychiatr Rehabil J 2016 Dec;39(4):364-367 [FREE Full text] [doi: 10.1037/prj0000207] [Medline: 27845533]

70. Rahal ZA, Vadas L, Manor I, Bloch B, Avital A. Use of information and communication technologies among individuals with and without serious mental illness. Psychiatry Res 2018 Aug;266:160-167. [doi: 10.1016/j.psychres.2018.05.026] [Medline: 29864616]

71. Sreejith G, Menon V. Mobile phones as a medium of mental health care service delivery: perspectives and barriers among patients with severe mental illness. Indian J Psychol Med 2019;41(5):428-433 [FREE Full text] [doi:

10.4103/IJPSYM.IJPSYM 333 18] [Medline: $\underline{31548765]}$

72. Pew Research Centre. 2019 Jun 12. Mobile Fact Sheet: Mobile Phone Ownership Over Time URL: https://www. pewresearch.org/internet/fact-sheet/mobile/ [accessed 2019-08-10]

\section{Abbreviations \\ RCT: randomized controlled trial \\ SMI: Severe Mental Illness}

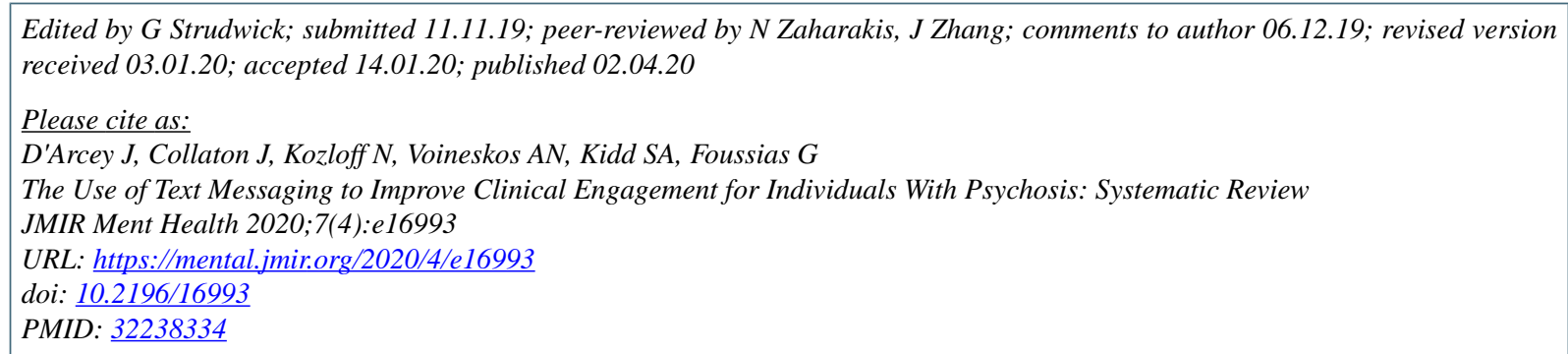

CJessica D'Arcey, Joanna Collaton, Nicole Kozloff, Aristotle N Voineskos, Sean A Kidd, George Foussias. Originally published in JMIR Mental Health (http://mental.jmir.org), 02.04.2020. This is an open-access article distributed under the terms of the Creative Commons Attribution License (https://creativecommons.org/licenses/by/4.0/), which permits unrestricted use, distribution, and reproduction in any medium, provided the original work, first published in JMIR Mental Health, is properly cited. The complete bibliographic information, a link to the original publication on http://mental.jmir.org/, as well as this copyright and license information must be included. 